\title{
Post Keynesian Theory and Evidence of Money Supply Endogeneity: A Review Essay
}

\author{
Sabri Nayan ${ }^{1}$, Norsiah Kadir ${ }^{2}$, Abdul Hafiz Yusof ${ }^{3}$, \& Noor Azillah Mohamad Ali ${ }^{3}$ \\ ${ }^{1}$ School of Economics, Finance and Banking (SEFB), College of Business (COB), Universiti Utara \\ Malaysia, Malaysia \\ ${ }^{2}$ Department of Economics, Faculty of Business Management, Universiti Teknologi Mara Malaysia \\ ${ }^{3}$ Department of Finance, Faculty of Business Management, University Teknologi Mara Malaysia \\ *Correspondence: Sabri Nayan, School of Economics, Finance and Banking, College of Business, \\ Universiti Utara Malaysia, 06010 Sintok Kedah, Malaysia. Tel: +604-9286795; E-mail: \\ sabri.nayan@uum.edu.my; sabrinayan585@yahoo.com.
}

DOI: $10.12735 /$ jee.v3i4p01

URL: http://dx.doi.org/10.12735/jfe.v3i4p01

\begin{abstract}
Money is the life-blood of any modern market-oriented economy. The level of money supply - the quantity and velocity of money circulated in such an economy would determine its health. The central issue in managing the economy is to understand how money supply is determined. The history of modern monetary economics actually has witnessed the emergence of two opposing views pertaining to the role of central bank in controlling the supply of money in an economy. A group of economists, known as monetarists, under the influence of Milton Friedman, contended that money supply in an economy is exogenously determined. Post Keynesian however holds the view that money supply is endogenously rather than exogenously determined. Examining the theory of endogenous money as well as empirical work, the present paper has found that money supply in several countries is endogenously determined.
\end{abstract}

JEL Classifications: E44, E52, E58

Keywords: endogenous, exogenous, horizontalist, Post Keynesian theory, structuralist

\section{Introduction}

Post Keynesian Economics is the contemporary version of Keynesian school of economic thought. It is an extension of the idea of John Maynard Keynes. Providing a new dimension to the modern economic thought and policy, Post Keynesian Economics stresses the endogeneity of money supply, the importance of uncertainty and historical time, the importance of effective demand in reducing unemployment rate and a rejection of neoclassical general equilibrium models (see i.e., Vernengo \& Rochon, 2001, p.77).

Post Keynesian Economics was actually developed by a group of economist from Cambridge who attempted to extend Keynes economic ideas and philosophy around 1980s. These economists insisted that economic theory must deal with problems in an institutional, historical time setting where uncertainty regarding future events colours current economic decisions and actions. The political, social and economic institutions of a non-neutral monetary system and the use of forward 
contracts represent fundamental aspects of the world which we inhabit and must play pivotal roles in any economic model that we develop.

The idea that money supply is endogenous is an extension to Keynes's (1930, 1972, \& 1936) ideas. The theory of endogenous money might actually be dated back to the $19^{\text {th }}$ century in Wicksell (1936). In his paper, Smithin (1997) presented a simple model combining both features of Keynes (1972) 'monetary production' economy, and Wicksell (1936) 'pure credit' economy. The basic idea behind the theory of endogenous money is that, "Production takes time and is financed by loans from financial intermediaries or banks" (Smithin, 1997, p.395).

This paper is organized in four sections. After introducing the paper in section one, the four branches (theories) of Post Keynesian approaches towards endogenous money is discussed in section two. The paper then provides evidence of endogenous money supply in section three before concluding in section four.

\section{Underlying Theory}

Money is the life-blood of any modern production economy. Correspondently, the stability, progress and the general welfare of such an economy would depend much on the level of its money supply as well as the monetary policy decisions and actions initiated by its monetary authority. Expressed differently, the levels of economic activity as well as stability, production and money supply in an economy are interrelated. The central issue then is, does the quantity of money supply determine the levels of economic activity and production? Alternatively, are economic activities and production the variables that actually determine the level of money supply in an economy? These questions are actually concerned with the endogeneity/exogeneity concept of money supply - an issue which is still unsettled at least in academia.

As can be found in the literature, the history of modern monetary economic has witnessed the emergence of two opposing views concerning the role of central bank in managing the supply of money and (indirectly) the level of economic activities in an economy. The first group of economist known as Monetarists, under the influenced of Milton Friedman, contended that money supply in an economy is exogenously determined. The second group of economists labelled as Post Keynesian economists - posited that money supply in an economy is endogenous rather than exogenous.

While nobody can still say for sure whether the supply of money in an economy is endogenously or exogenously determined, this issue is crucial for a proper formulation of macroeconomic policy. Every macroeconomic and monetary policy should of course, aimed at maintaining price stability, steady economic growth, high employment rate and stability of financial markets.

That money supply in an economy is endogenous; that the level of money supply is primarily determined by the activities of commercial banks in response to the demand for credits by economic units - as noted above, is a proposition put forward by a group of economists popularly known as Post Keynesian economists. Basil Moore's name is always associated with bringing the concept of endogenous money to the attention of economists in the last decade of twentieth century. In the literature of Post Keynesian economics, money supply endogeneity has been studied based on four hypotheses. These four 'sub-school' or branches of Post Keynesian economics are popularly known as Horizontalist, Structuralist, Liquidity Preference View and Circuit Theory of Money.

\subsection{Horizontalism}

The main proponents of the horizontalist view can be found in the writings of Kaldor (1982) and Moore (1988). The money supply process based on the horizontalist view implies that loans create deposits, so deposits are endogenously determined. Changes in the money supply are a result of, and not a cause of, changes in money income, and vary in relation to prices and output. Based on 
the premise that money supply in an economic system is endogenously determined, horizontalists have proposed the following (causal) relationship between three pairs of monetary variables:

- "The core of the endogeneity thesis is that money supply is determined by the demand for bank lending. This in turn depends upon the 'state of trade', essentially the level of nominal output." (Howells, 1995). In Le Bourva's (1992, p. 447) words, "The supply of money is a dependent variable, not an independent one. The demand for credit determines the quantity of money ...." (See also Moore, 1998)

- The causal relationship between money-income (or the GDP) and monetary aggregate (MA) is bidirectional. As Nell's (2000) put it, "The accommodationist approach implies bidirectional causality between money income ... and the M3 money supply...Borrowers who are financing investment spending base their loan demand on the expectation that income will rise in the future...Loans cause deposits, but the newly created deposits finance increases in aggregate demand...." (See i.e., Davidson, 1978; Moore, 1998).

- Panagopoulos and Spiliotis (2008), the causal relationship between bank credit (BC) and monetary base (MB) should be unidirectional, in the sense that it is $\mathrm{BC}$ that causes changes in MB (Nell, 2000; Panagopoulos \& Spiliotis, 2008).

\subsection{Structuralism}

According to Structuralism, although economic agents and firms play an important role in the economic system, the central bank is a significant player and has the privilege to deny accommodation of reserve needs and consequently resist credit expansion (Panagopoulos \& Spiliotis, 2008).

Further, Nell (2000) stressed that an important feature of the structuralist endogeneity approach is their emphasis on liability management practices, allowing banks to partly overcome reserve constraints imposed by the central bank. Structuralist argues that liability management need not necessarily create an adequate supply of reserve to meet demand, and therefore the rise in the rate of interest within a given financial structure is inevitable (see also Pollin, 1991).

Panagopoulos and Spiliotis (2008, p.603) underlined the role of multiplier in the economic system. According to the authors, Structuralists accepts that loans create deposits and deposits make reserves. "Their position is completed when bank credit (BC) is in a feedback relation with the monetary base (MB) as well as with the money multiplier." (See also Nell, 2000).

Regarding the money-income relationship, Panagopoulos and Spiliotis $(2008$, p.604) noted that the endogeneity of money generating process, on the one side, and the partial ability of the central bank to control the quantity banks' liabilities, on the other side, has driven many economists to consider the feedback rule or bidirectional causality relationship between GDP and MA (See also Nell, 2000).

The above discussion reveals that structuralism is different from horizontalism, since they believe in feedback rule (or bidirectional causal relationship) between the following pairs of variables: Bank credit $(\mathrm{BC})$ and monetary base $(\mathrm{MB})$; Bank credit $(\mathrm{BC})$ and money multiplier (MMPR); and Money-income (GDP) and monetary aggregates (MA).

\subsection{Liquidity Preference (LP) View}

This approach to Post Keynesian monetary economics also supports the horizontalist core theoretical arguments in favor of an endogenously determined money supply in an economy. The only difference between Liquidity Preference and Horizontalism is on the role of "excess money" supply. More precisely, Liquidity Preference economists's main criticism is based on the assumption made by horizontalists that credit money can never be in "excess" supply, and hence 
that there is no independent money demand function (Goodhart, 1989; Palley, 1991; Arestis \& Howells, 1999; Howells, 1997).

Based on the aforementioned premise, Liquidity Preference (LP) economists, hypothesize that: The causal relationship between $\mathrm{BC}$ and MA is bidirectional (feedback rule): In the first case of the causality that $\mathrm{BC}$ causes MA is based on the assumption that money is endogenously determined. The reverse assumption (that MA causes BC) is based on the theory of an "effective amount of deposits held," representing the existence of an independent demand for money (Panagopoulos \& Spiliotis, 2008); The entire LP reconciliation mechanism challenges the stability of the credit multiplier and is expected to produce feedback effects between itself (MMPR) and bank credit (Nell, 2000); and The relationship between money income (or GDP) and the "effective amount of deposit held" (e.g., M1, M2), underlined the following: First, LP theorists like other Post Keynesians, accepted that loans are demand driven and therefore we can infer that they partially recognize the "income causes money" process. Second, as Howells's (1997, p.433) reconciliation mechanism puts it, when people have particular preferences in holding wealth (e.g., deposits), this "causes them to rearrange their portfolios with consequences for prices, output, interest rates, and so on".

\subsection{Circuit Theory of Money (CTM)}

The concept of monetary circuit as defined by Gnos and Rochon (2003) refers to the firms' successive outlays (for productive factors) and receipts (from sales), and to the resulting formation and cancellation of money incomes. Robinson (1956) mentioned this term in the very first page her book The Accumulation of Capital, as 'the cycle of production and sales'.

Robinson's (1956) analysis begins with the hierarchy of production. There are essentially three sectors in Robinson's production 'model': In this model, banks have the task of financing the production process through the creation of money, and of selecting business plans (Realfonzo, 1998, p.61). In this process, firms, through access to credit, buy factors of production and direct the production process, making decisions on the quantity of output. Workers play their role as suppliers of labor services. Clearly in this model, money (or credit) plays a crucial role in ensuring the smooth function of the economy (or production process).

According to Rochon (2001), and Vernengo and Rochon (2001), Robinson endorsed a theory of endogenous money. However, Gnos and Rochon (2003) extended this analysis to show that Robinson (1956) views are also related to the theory of the monetary circuit. In such monetary circuit model, money supply generation (and 'destruction') process is the result of the complexity and the links between three specific causal relationships - banks and firms, firms and workers, and banks and households.

\section{Evidence of Money Supply Endogeneity}

Le Bourva, through his two papers published in 1959 and 1962, is actually the one who puts the foundation for the developments of a branch of Post Keynesian Economics known as the theory of money supply endogeneity. This theory in its 'organized' form however, started in the late 1970s with the publication of the Journal of Post Keynesian Economics in 1979. Among the earliest papers published in this Journal are by Moore (1983 \& 1988). This suggests that the theory of money supply endogeneity is a relatively new theory, since the empirical works examining money supply endogeneity only started in the early 1980s.

Being a relatively new theory, empirical works examining money supply endogeneity only started in the early 1980s. Kaldor (1982) was among the earliest economists who empirically investigated this theory. He analyzed the data for the UK for a sample period of 1966 through 1979 by utilizing the Ordinary Least Square (OLS) method. His findings suggested that money supply is 
determined by the demand for bank lending, hence appears to be among the earliest evidence of money supply endogeneity.

Moore (1983) extended this evidence for the U.S. economy, using quarterly data spanning from 1964 to 1979 , to analyze the demand for bank loans to commercial and industrial corporations. His finding cited that, in order to finance their working capital, firms increase their demand for loans (particularly for the purpose of paying wages). Thus, financing for working capital appears to be the most important determinant of bank lending to companies.

It is interesting to note that Moore's (1983) finding on the literature of the monetary authorities to control the rate of bank credit expansion, thus implying that money supply in the U.S. is endogenous. The behavior of money wage rates, both as a component of companies' demand for working capital finance and as determinants of disposable personal income, plays a central role in determining private demand for bank credit. Whenever money wages are rising rapidly, it will prove very difficult for the Federal Reserve to restrict the rate of monetary growth.

Strictly speaking, when monetary authorities (central banks) change interest rates, it because a "refinancing" rate, the rate at which liquidity is made available to the banking sector. It is only in the market for reserves that the bank is the monopoly supplier and only in that market that it can determine price directly. The deputy governor of Bank of England's once noted "the Bank of England supplies base money on demand at its prevailing interest rate, and broad money is created by the banking system" (King, 1994, p.264). What happens as broad money is created is determined by behavioral interactions among private sector agents. This includes what happens to market interest rates, the ones that genuinely impinge on real economic activity.

Panagopoulos and Spiliotis (1998) conducted an empirical study of the commercial banks' lending behavior in Greece and revealed that credit money was primarily determined by the banking system in response to the demand for loans. In their conclusion, Panagopoulos \& Spiliotis (1998, p.670) underlined that "evidence verifies the Post Keynesian approach that, in modern economies, the credit-money supply process is an endogenous one".

Vera (2001) provided other evidence that the supply of credit money is endogenous. Using the time series data from Spain (for the period 1987-1998), a Granger causality tests were run between the monetary base, bank lending, and various money multipliers. The evidence is strongly consistent with the hypothesis that the money supply was credit-driven and demand-determined. Granger causality was found to run from bank lending to the base, and to the money supply, and not from the base to the money supply and to loans, as the mainstream view maintains.

The results were consistent with both the accommodationist and the structuralist approach. This Granger causality runs predominantly from bank lending to the various money multiplier, actually has an interesting policy implication: "the hypothesis that liability management practices were a significant device for the accommodation of loan demand in Spain" (Vera, 2001, p. 524).

Atesoglu (2003) studied the relationship between federal funds rate and prime rate based on USA data for two sample periods (1987 - 1994 and 1994 - 2002). Empirical evidence from both sample periods revealed a positive cointegration relation representing a pass-through from the federal funds rate to the prime rate. Results from the earlier sample period revealed a two-way causality between the federal funds rate and the prime rate. In contrast, the results from the latter sample period indicate that causality runs from federal funds to the prime rate. These findings are supportive of the interest rate channel of monetary transmission and are supportive of the monetary transmission process emphasized by Post Keynesians.

Results from the earlier sample period (during which the Fed kept the federal funds rate target confidential) revealed a two-way causality between the federal funds rate and the prime rate. These results provide support to the structuralist Post Keynesian explanation of money supply endogeneity. In contrast, the results from the latter sample period (during which the federal funds rate was made 
public) indicate that causality runs from the federal funds rate to the prime rate, which supported to the Post Keynesian view who emphasize the horizontalist endogeneity approach to the determination of money supply. Atesoglu findings are considered interesting on the following grounds:

- Majority of previous studies uses bank lending and money supply to detect the endogeneity of money supply, whereas Atesoglu used interest rates (both short and long term rates);

- He indicated that, changes in the federal funds rate and prime rate in recent years have increased the effectiveness of monetary policy. Monetary policy actions engineered through the federal funds rate by the Federal Reserve are now rapidly and completely transmitted to the prime rate, which in turn forms the basis for other interest rates charged by banks; and

- The findings using the USA data, are consistent with a monetary transmission mechanism in which changes in the federal funds rate (brought about by the Federal Reserve) through open market operations, lead to changes in long-term interest rates. This revealed that there is an empirically stable long run relation and a unidirectional causality from the federal funds rate to the long term interest rates, parallel to the the horizontalist view of the money supply endogeneity.

Another evidence of money supply endogeneity was from Vymyatnina (2006) using the Russian data. However, different from previous studies (monetarist view), Vymyatnina found that inflation leads to money supply growth. Such the findings supported the endogenous money supply view.

Lavoie (2005) examined the monetary based endogeneity of the Canadian economy. His findings suggested that asset-based financial system, just like credit in financial systems, rely on a fully endogenous supply of high-powered money, with central bank engaging essentially in "defensive" operations. This is demonstrated through an analysis of the Canadian monetary process with the overnight rate closely gravitating around the target overnight rate. Central bank of Canada knows with perfect certainty both its supply of and the demand for settlement balances (Lavoie, 2005). Thus, money supply in Canada is endogenous.

Ahmad and Ahmed (2006) studied Pakistan monthly data based on a sample period of twenty-four years (i.e., 1980 - 2003) came up with interesting findings that might have some implications for future research on money supply endogeneity. Among the salient features are: Pakistan money supply for the period of $1980-2003$ is endogenously determined in the short run; They claimed that their empirical results supported both the Structuralists and the Liquidity Preference views on the money supply endogeneity; However, their results only provide partial support to the Accommodationists' view of money supply endogeneity; and different from other studies of money supply endogeneity, in the long-run their findings indicated that it is the base money that determines the total bank advances, versus otherwise. In principle they concluded that the central bank of Pakistan has some considerable on money supply in the long run.

Similar to Ahmad and Ahmed (2006), Cifter and Ozun (2007) also utilized Granger Causality and Vector Error Correction (VECM) methodology to examine money endogeneity in a developing country. Aimed at testing monetary transmission mechanism and passive money (or money supply endogeneity) hypothesis, they used seven types of variables: money base, money supply, credit capacity, industrial production index (i.e., the proxy for the GDP), interest rates, inflation and real exchange rate. They used quarterly data for the sample periods of ten years, ranging from 1997 to 2006. Listed are among the major outcomes of their study: The endogeneity money supply hypothesis of the Post Keynesian economics is supported in part by Accommodationists view but differ from those of Structuralist and Liquidity Preference theories; The results from money transmission mechanism analysis suggested that, long term money supply effects price levels, while production was detected to have influenced interest rates during the sample period of the study; and 
for the Turkish economy during the sample period of the study, interest rates are at the forefront in the monetary transmission mechanism of the economy.

Among the latest empirical works examining the theory of money supply endogeneity is the one by Panagopoulos and Spiliotis (2008). Based on the objective of presenting "the ways different schools of economic thought approach the money supply process - that is, the money-income relationship as well as the money multiplier model" (p. 601). They examined the data from G7 countries (for a period of 1980 through 2003). Given the findings of this study, the authors then concluded that, "most of the G7 economies - with the exception of France and possibly Japan seem to follow a nonorthodox road regarding the money generation process" (p. 618).

In addition, Badarudin, Ariff and Khalid (2011), investigated the relationship between money supply endogeneity and bank stock returns. Interestingly, a new evidence of positive and significant relationship between endogenous money supply and aggregate bank stock return. These findings are parallel and consistent with the view of Post Keynesians monetary theory and the dividend valuation theory, which predicts money supply changes to induce changes in bank earnings, so bank share price change.

Further, Badarudin, Khalid and Ariff (2012), investigates the nature of money supply in Australia. The Post Keynesian theory on endogenous money was tested with the aim of investigating whether endogenous money supply, if it did exist, followed the accommodationist, structuralist or liquidity preference viewpoints. Interestingly, they found that money supply is endogenous in Australia even when the central bank targeted monetary aggregates during the period 1977 to 1993 . Based on their findings, loans cause money supply in the long-run and there is bidirectional causality in the short-run. This indicates a support for accommodationist view in the long-run and the structuralist view in the short run. Further, during the inflation targeting regime, the evidence for bidirectional long-run causality is found, which evidence is consistent with the liquidity preference view. This shows that deposit owners have independent liquidity preferences about the amount of money they wish to hold. In the short-run, the accommodationist hypothesis is supported as loans appear to cause money supply.

According to Lucarelli (2013), Keynes's finance motive provides an important starting point in Post Keynesian theories of endogenous money. Despite their divergent and conflicting approaches, there is a general consensus among Post Keynesians that capitalist money is essentially endogenous. The Monetarist causation is reversed: the demand for money and credit determines its supply both in the long run and in the short run, from which it follows that the doctrine of long-run monetary neutrality also breaks down.

By utilizing system GMM method, Nayan, Kadir, Abdullah and Ahmad (2013) investigates the theory of money supply endogeneity based on a panel dataset of 177 counties and has found that money supply is endogenous as proposed by Post Keynesian theorists. In addition, they view that monetary authorities in major economies of the world have considered money supply as endogenous and hence, interest rates are treated to be exogenous. If the supplies of money in these economies are actually endogenous, then interest rate targeting approach in managing the economy would be the appropriate and effective policy.

\section{Conclusion}

It is interesting to note that Peter Howells (Howells, 1997) one of the major contributor to the development of money endogeneity theory, had demonstrated and declared that "we" are all endogenous money "now". Perhaps, since our empirical evidences that money supply in several countries is endogenously determined, we could also be considered as endogenous money empiricist. In line with this argument, we concluded that: 
Credit is the pavement along which production travels; and bankers if they knew their duties, would provide the transport facilities to just extent that is required in order that the productive powers of the community can be employed to their full capacity (Keynes, 1930, p.219-220).

\section{Acknowledgements}

The authors would like to thank an anonymous referee of this journal for helpful comments. We also thankful for the financial support provided by Research Acculturation Grant Scheme (RAGS/2012/UiTM/SS07/3). The opinions in this article correspond to the authors and do not necessarily reflect to point of view of UiTM and UUM. Finally, we thank Mat Saad Abdullah for his excellent view and proof reading the article).

\section{References}

[1] Ahmad, N., \& Ahmed, F. (2006). The long-run and short-run endogeneity of money supply in Pakistan: An empirical investigation. SBP-Research Bulletin, 2(1), 267-278.

[2] Arestis, P., \& Howells, P. (1999). The supply of credit money and the demand for deposits: A reply. Cambridge Journal of Economics, 23(1), 115-119.

[3] Atesoglu, H. S. (2003). Monetary transmission - federal funds rate and prime rate. Journal of Post Keynesian Economics, 26(2), 357-362.

[4] Badarudin, Z. E., Ariff, M., \& Khalid, A. M. (2011). Money supply endogeneity and bank stock returns. Applied Financial Economics, 21(14), 1035-1048.

[5] Badarudin, Z. E., Khalid, A. M., \& Ariff, M., (2012). Exogenous or endogenous money supply: Evidence from Australia. The Singapore Economic Review, 57(4), 1-12.

[6] Cifter, A., \& Ozun, A. (2007). The monetary transmission mechanism in the new economy: Evidence from Turkey (1997-2006). South East European Journal of Economics and Business, 2(1), 15-24.

[7] Davidson, P. (1978). Money and the real world (2nd ed.). London: MacMillan.

[8] Gnos, C., \& Rochon, L.-P. (2003). Joan Robinson and Keynes: Finance, relative prices and the monetary circuit. Review of Political Economy, 15(4), 483-491.

[9] Goodhart, C. (1989). Has Moore become too horizontal? Journal of Post Keynesian Economics, 12(1), 29-34.

[10] Howells, P. G. A. (1995). The demand for endogenous money. Journal of Post Keynesian Economics, 18(1), 89-106.

[11] Howells, P. G. A. (1997). The demand for endogenous money: A rejoinder. Journal of Post Keynesian Economics, 19(3), 429-435.

[12] Kaldor, N. (1982). The scourge of monetarism. London: Oxford University Press.

[13] Keynes, J. M. (1930). A treatise on money (Vol. I \& II). New York: Harcourt, Brace and Company.

[14] Keynes, J. M. (1936). The general theory of employment, interest and money. London: Prometheus Books.

[15] Keynes, J. M. (1972). Essays in biography (Vol. X) - The collected writings of John Maynard Keynes [D. Moggridge (ed.)]. London: MacMillan. 
[16] King, M. (1994). The transmission mechanism of monetary policy. Bank of England Quarterly Bulletin, 34(3), 261-267.

[17] Lavoie, M. (1992), Jacques Le Bourva's theory of endogenous credit-money, Review of Political Economy, 4 (4), 436-446.

[18] Lavoie, M. (2005). Monetary base endogeneity and the new procedures of the asset-based Canadian and American monetary systems. Journal of Post Keynesian Economics, 27(4), 689-709.

[19] Le Bourva, J. (1992). Money creation and credit multipliers. Review of Political Economy, 4(4), 447-466.

[20] Lucarelli, B. (2013). Endogenous money: A note on some post-keynesian controversies. Review of Political Economy, 25(2), 348-359.

[21] Moore, B. J. (1983). Unpacking the post Keynesian black box: Bank lending and the money supply. Journal of Post Keynesian Economics, 5(4), 537-556.

[22] Moore, B. J. (1988). The endogenous money supply. Journal of Post Keynesian Economics, $10(3), 372-385$.

[23] Moore, B. J. (1998). Accommodation to accommodationism: A note. Journal of Post Keynesian Economics, 21(1), 175-178.

[24] Nayan, S., Kadir, N., Abdullah, M. S., \& Ahmad, M., (2013). Post Keynesian endogeneity of money supply: Panel evidence. Procedia Economics and Finance, 7, 48-54.

[25] Nell, K. S. (2000). The endogenous/exogenous nature of South Africa's money supply under direct and indirect monetary control measures. Journal of Post Keynesian Economics, 23(2), 313-329.

[26] Palley, T. I. (1991). The endogenous money supply: Consensus and disagreement. Journal of Post Keynesian Economics, 13(3), 397-403.

[27] Panagopoulos, Y., \& Spiliotis, A. (1998). The determinants of commercial banks' lending behavior: some evidence for Greece. Journal of Post Keynesian Economics, 20(4), 649-672.

[28] Panagopoulos, Y., \& Spiliotis, A. (2008). Alternative money theories: A G7 testing. Journal of Post Keynesian Economics, 30(4), 601-622.

[29] Pollin, R. (1991). Two theories of money supply endogeneity: Some empirical evidence. Journal of Post Keynesian Economics, 13(3), 366-396.

[30] Realfonzo, R. (1998). Money and banking, theory and debate (1900-1940). Cheltenham, UK: Edward Elgar.

[31] Robinson, J. (1956). The accumulation of capital. London: Macmillan.

[32] Rochon, L.-P. (2001). Cambridge's contribution to endogenous money: Robinson and Kahn on credit and money. Review of Political Economy, 13(3), 287-307.

[33] Smithin, J. (1997). An alternative monetary model of inflation and growth. Review of Political Economy, 9(4), 395-409.

[34] Vera, A. P. (2001). The endogenous money hypothesis: Some evidence from Spain (1987-1998). Journal of Post Keynesian Economics, 23(3), 509-526.

[35] Vernengo, M., \& Rochon, L.-P. (2001). Kaldor and Robinson on money and growth. The European Journal of the History of Economic Thought, 8(1), 75-103. 
[36] Vymyatnina, Y. (2006). How much control does bank of Russia have over money supply? Research in International Business and Finance, 20(2), 131-144.

[37] Wicksell, K. (1936). Interest and prices. (R. F. Kahn, trans.). London: Macmillan. (Original work published 1898).

\section{Copyrights}

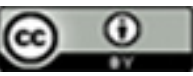

Copyright for this article is retained by the author(s), with first publication rights granted to the journal. This is an open-access article distributed under the terms and conditions of the Creative Commons Attribution 4.0 International License.

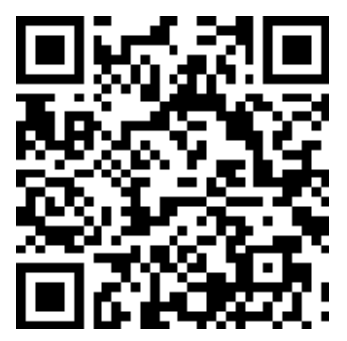

